\title{
PENGARUH KOMPOSISI MEDIA TANAM DAN PEMBERIAN DOSIS PUPUK PGPR (Plant Growth Promoting Rhizobacteria) TERHADAP PERTUMBUHAN SEMAI KETIMUNAN (Gyrinops versteegii)
}

The Effect of the Composition of Planting Media and The Giving of PGPR (Plant Growth Promoting Rhizobacteria) on the Growth Seedling of Cucumber (Gyrinops Versteegii)

\author{
Ansari Firmansyah, Markum, Indriyatno \\ Program Studi Kehutanan, Universitas Mataram \\ JI Majapahit No 62, Mataram, NTB \\ Email ; markum.exp@gmail.com
}

\begin{abstract}
The aims of this research were to identify the effect of planting media and the giving of fertilizer PGPR. The method applied in this research was an experimental method using complete random planning that consists of 2 factorial. The first-factor consists of 4 borders: compost $(P \neg \neg 0)$, compost+cocopeat with proportion 1:1 (P1), cocopeat $(P \neg 2)$, and compost+cocopeat with proportion 1:2 (P3). The second factor was without the fertilizer PGPR (FO), fertilizer dosage $100 \mathrm{ml}$ (F1), fertilizer dosage $200 \mathrm{ml}$ (F2), fertilizer dosage $300 \mathrm{ml}$ (F3). The combination of those factors yield 16 treatments, each combination of the treatments was repeated 3 times, in which every repetition had 4 plants, that the number of the samples was 192. The observed parameters in this research were the percentage of the growing plants, the height of the plant, the diameter of the stem, the number of the leaves plants, and the strength of the plants. The result of the observation was tested using analysis of variance at a level of reality $1 \%$. The result of the observation showed that planting media and fertilizer PGPR had an insignificant effect on the observed parameter.
\end{abstract}

Keywords: Fertilizer PGPR, planting media, Gyrinops versteegii.

\section{ABSTRAK}

Tujuan penelitian ini adalah untuk mengetahui pengaruh media tanam dan dosis pupuk Plant Growth Promoting Rhizobacteria (PGPR) terhadap pertumbuhan semai gaharu, serta mengetahui interaksi antara media tanam dan dosis pupuk PGPR. Metode yang digunakan dalam penelitian ini adalah metode eksperimental menggunakan Rancang Acak Lengkap (RAL) yang terdiri dari 2 faktorial. Faktor pertama adalah media tanam yang terdiri dari 4 aras yaitu kompos $\left(P_{0}\right)$, kompos+cocopeat perbandingan 1:1 $\left(P_{1}\right)$, cocopeat $\left(P_{2}\right)$, dan kompos+cocopeat dengan perbandingan 1:2 $\left(P_{3}\right)$. Faktor kedua adalah tanpa penggunaan pupak PGPR $\left(F_{0}\right)$, dosis pupuk $100 \mathrm{ml}\left(\mathrm{F}_{1}\right)$, dosis pupuk $200 \mathrm{ml}\left(\mathrm{F}_{2}\right)$, dosis pupuk $300 \mathrm{ml}\left(\mathrm{F}_{3}\right)$. Dari kombinasi kedua faktor tersebut dihasilkan 16 perlakuan, setiap kombinasi perlakuan terdiri dari 3 ulangan, dimana pada masing-masing ulangan terdapat 4 tanaman, sehingga mengasilkan 192 sampel penelitian. Parameter yang diamati pada penelitian ini adalah persentase hidup, tinggi tanaman, diameter batang tanaman, jumlah daun tanaman dan kekokohan tanaman. Hasil pengamatan diuji menggunakan analisis 
sidik ragam pada taraf nyata 1\%. Dari hasil pengamatan menunjukkan bahwa media tanam dan pupuk PGPR tidak berpengaruh nyata terhadap parameter yang diamati.

Kata Kunci: Pupuk PGPR, media tanam, Gyrinops versteegii.

\section{Pendahuluan}

Dalam proses perjalanan waktu, kondisi kawasan hutan kian menurun dari segi kuantitas maupun kualitas (Hairiah et al., 2004). Ada banyak faktor pemicu kerusakan hutan seperti illegal logging, pembukaan areal baru untuk pemukiman, izin perkebunan dan atau izin lain yang implementasinya di dalam kawasan hutan. Ada banyak upaya yang dapat dilakukan guna memperbaiki kondisi hutan, diantaranya yaitu penanaman kembali pada kawasan hutan yang telah mengalami kerusakan, yang tentu saja dalam hal ini terlebih dahulu dilakukan persemaian.

Ada banyak faktor kunci yang perlu diperhatikan dalam kegiatan persemaian, salah satu diantaranya yaitu media tanam. Selama ini kegiatan persemaian sangat mengandalkan penggunaan tanah lapisan atas (Top soil) sebagai media tanam. Penggunaan top soil ini memberi dampak negatif terhadap lingkungan seperti peningkatan tingkat erosi, penurunan kualitas tanah akibat hilangnya unsur hara, hilangnya habitat mikroorganisme dekomposer. Beberapa opsi alternatif yang pernah dan lazim digunakan sebagai pengganti media tanam adalah kompos dan serabut kelapa (cocopeat), mengingat ketersediaannya yang melimpah dan mudah untuk didapatkan. Selain media tanam, penggunaan pupuk organik juga merupakan faktor yang penting dalam menunjang keberhasilan persemaian, salah satunya adalah pupuk organik cair jenis PGPR (Plant Growth Promoting Rhizobacteria).

Salah satu jenis tanaman yang pada saat ini banyak dibudidayakan di NTB adalah tanaman ketimunan atau gaharu (Gyrinops versteegii). Menurut Sumarna (2012) berkembangnya nilai guna gaharu, mendorong minat negara-negara industri untuk memperoleh gaharu dengan harga jual yang semakin meningkat. Tingginya harga jual mendorong upaya masyarakat merubah pola produksi, semula hanya memanfaatkan dan atau memungut dari pohon produksi yang telah mati alami, kini dilakukan dengan cara menebang pohon hidup dan mencacah bagian batang untuk memperoleh bagian kayu yang telah bergaharu. Upaya untuk kelestarian sumberdaya pohon penghasil di berbagai wilayah sebaran tumbuh. Maka sangat perlu dilakukan budidaya tanaman gaharu (Gyrinops versteegii) melalui penelitian penggunaan media tanam alternatif untuk pembibitan gaharu tersebut.

\section{Metode}

Penelitian ini dilakukan bulan Juni-Agustus tahun 2014 yang bertempat di Kebun Percobaan Program Studi Kehutanan Universitas Mataram. Metode yang digunakan dalam penelitian ini adalah metode eksperimental, yang dirancang dengan Rancangan Acak Lengkap (RAL) yang ditata secara faktorial yang terdiri atas dua faktor dan dilakukan dengan tiga kali ulangan. Faktor pertama adalah media tanam yang terdiri dari 4 aras yaitu kompos $\left(P_{0}\right)$, kompos+cocopeat perbandingan 1:1 $\left(P_{1}\right)$, cocopeat $\left(P_{2}\right)$, dan kompos+cocopeat dengan perbandingan 1:2 $\left(\mathrm{P}_{3}\right)$. Faktor kedua adalah tanpa penggunaan pupak PGPR $\left(F_{0}\right)$, dosis pupuk $100 \mathrm{ml}\left(\mathrm{F}_{1}\right)$, dosis pupuk $200 \mathrm{ml}\left(\mathrm{F}_{2}\right)$, dosis pupuk $300 \mathrm{ml}$ $\left(F_{3}\right)$. Dari kombinasi kedua faktor tersebut dihasilkan 16 perlakuan, setiap kombinasi 
perlakuan terdiri dari 3 ulangan, dimana pada masing-masing ulangan terdapat 4 tanaman, sehingga mengasilkan 192 sampel penelitian. Pelaksanaan penelitian ini meliputi tahap persiapan, tahap pemeliharaan, dan tahap pengamatan. Parameter yang diamati adalah persentasi hidup (\%), tinggi semai $(\mathrm{cm})$, diameter semai $(\mathrm{cm})$, jumlah daun (helai), dan kekokohan semai. Analisis data menggunakan analisis varians pada taraf nyata $1 \%$.

\section{Hasil Dan Pembahasan}

\section{Hasil Analisis Pupuk Kompos}

Analisis pupuk kompos bertujuan untuk mengevaluasi unsur hara yang terkandung dalam pupuk kompos dan pupuk PGPR, pada dasarnya analisis unsur hara bertujuan untuk mengetahui ketersediaan unsur hara yang terdapat di dalam pupuk itu sendiri. Adapun kandungan unsur hara yang terdapat pada pupuk kompos dapat dilihat pada Tabel 1 di bawah ini.

Tabel 1 Data Hasil Analisis Unsur Hara dalam Pupuk Kompos dan Pupuk Plant Growth Promoting Rhizobacteria (PGPR)

Table 1. Data result of analysis nutrient in compost and PGPR

\begin{tabular}{llclcl}
\hline No. & Sifat pupuk & \multicolumn{3}{c}{ Pupuk } \\
\cline { 3 - 6 } & & \multicolumn{3}{c}{ Kompos } & \multicolumn{1}{c}{ PGPR } \\
\cline { 3 - 6 } & & Nilai (\%) & \multicolumn{1}{c}{ Harkat ${ }^{\star}$} & Nilai (\%) & \multicolumn{1}{c}{ Harkat $^{\star}$} \\
\hline 1 & Kadar Lengas & 3,22 & - & 0,00 & - \\
2 & pH $\left(\mathrm{H}_{2} \mathrm{O}\right)$ & 6,6 & Netral & 3,4 & Sangat Masam \\
3 & C-Organik & 4,41 & Tinggi & 3,96 & Tinggi \\
4 & N-Total & 0,45 & Sedang & 0,11 & Rendah \\
5 & P-Total & 0,52 & Sangat tinggi & 0,02 & Sangat tinggi \\
6 & K-Total & 0,72 & Sangat tinggi & 0,42 & Sangat tinggi \\
\hline
\end{tabular}

Keterangan: *Balai Penelitian Tanah, Badan Penelitian dan Pengembangan Pertanian Departemen Pertanian (BP3DP, 2005).

Pada Tabel 1. dapat dilihat bahwa $\mathrm{pH}$ pupuk kompos menunjukkan nilai sebesar 6,6, menurut BP3DP (2005) nilai tersebut tergolong dalam kelas netral. Sementara pada pupuk PGPR terlihat nilai pH sebesar 3,4, menurut BP3DP (2005) nilai tersebut tergolong dalam kelas sangat masam. Hardjowigeno (2007) menjelaskan bahwa tujuan dari mengetahui nilai $\mathrm{pH}$ yaitu untuk menentukan mudah tidaknya unsur-unsur hara diserap oleh tanaman, umumnya unsur hara mudah diserap akar tanaman pada $\mathrm{pH}$ sekitar netral, karena pada $\mathrm{pH}$ tersebut unsur hara mudah larut dalam air. Pada tanah masam unsur $\mathrm{P}$ tidak dapat diserap tanaman karena diikat (difiksasi) oleh Al, begitu juga pada tanah alkalis unsur $\mathrm{P}$ tidak dapat diserap tanaman karena diikat (difiksasi) oleh $\mathrm{Ca}$.

Dari hasil analisis kompos yang telah dilakukan, didapatkan kandungan $\mathrm{N}$ total menunjukkan nilai sebesar 0,45\%, menurut BP3DP (2005) nilai $\mathrm{N}$ total tersebut tergolong kedalam harkat sedang. Sementara pada pupuk PGPR nilai $\mathrm{N}$ total menunjukkan nilai sebesar $0,11 \%$, nilai tersebut tergolong dalam kelas sangat rendah (BP3DP, 2005). Unsur $\mathrm{N}$ berfungsi untuk meningkatkan pertumbuhan tanaman, menyehatkan hijau daun (khlorofil), meningkatkan kualitas tanaman yang menghasilkan daun. Kelebihan $\mathrm{N}$ mengakibatkan jaringan mudah patah, mudah terserang parasit dan infeksi, sebaliknya 
gejala kekurangan $\mathrm{N}$ yaitu terdapatnya penyimpangan pertumbuhan daun, mengering, serta tanaman kerdil (Sutedjo dan Kartasapoetra, 1991).

Hasil analisis unsur $\mathrm{P}$ pada pupuk kompos menunjukkan nilai sebesar $0,52 \%$ dan pada pupuk PGPR menunjukkan nilai sebesar 0,02\%. Menurut BP3DP (2005) nilai tersebut sudah termasuk dalam harkat sangat tinggi. Unsur $\mathrm{P}$ sangat penting bagi tanaman karena berfungsi untuk perkembangan akar, pembelahan sel, memperkokoh batang agar tidak mudah roboh, menyimpan dan memindahkan energi, serta membuat tanaman tahan terhadap penyakit (Hardjowigeno, 2007).

Dari hasil analisis $\mathrm{K}$ menunjukkan nilai sebesar $0,72 \%$, dan pada pupuk PGPR terlihat $\mathrm{K}$ menunjukkan nilai sebesar 0,42\%. Menurut BP3DP (2005) nilai tersebut termasuk dalam harkat sangat tinggi, Menurut Soeryoko (2011), Kalium merupakan salah satu unsur hara yang sangat dibutuhkan oleh tanaman dalam jumlah besar. Kalium banyak diberikan pada tanaman yang dipanen bunga maupun buahnya. Adapun manfaat dari unsur kalium bagi tanaman yaitu untuk proses fotosintesis, perkembangan sel, pengaturan stomata, pengaturan air dan pembuatan protein, pembentuk karbohidrat dan gula, serta memperkuat daya tahan tanaman terhadap penyakit.

Dari hasil analisis kadar lengas sampel pupuk menunjukkan nilai sebesar $3,22 \%$. Hardjowigeno (2007), menerangkan bahwa air sangat mempengaruhi pertumbuhan tanaman. Kelebihan atau kekurangan air dapat mengganggu pertumbuhan tanaman, adapun kegunaan air bagi tanaman diantaranya yaitu sebagai unsur hara bagi tanaman, sebagai pelarut unsur hara, dan sebagai bagian dari sel-sel tanaman.

\section{Hasil Analisis Pertumbuhan Tanaman}

Berdasarkan perbedaan dosis pupuk PGPR dan jenis media tanam yang digunakan, untuk mengetahui perbedaan pertumbuhan tanaman gaharu (Gyrinops versteegii), diperoleh hasil pengukuran yang kemudian dilakukan analisis sidik ragam (Anova) sebagaimana ditunjukkan pada Tabel 2 di bawah ini:

Tabel 2 Hasil Analisis Sidik Ragam Parameter Penelitian Table 2 Results of Analysis of Parameter Sidik Variety Research

\begin{tabular}{clccc}
\hline No. & \multicolumn{1}{c}{ Parameter } & Media Tanam & $\begin{array}{l}\text { Dosis Pupuk } \\
\text { PGPR }\end{array}$ & $\begin{array}{l}\text { Media Tanam }{ }^{\star} \text { Dosis } \\
\text { Pupuk PGPR }\end{array}$ \\
\hline 1 & Persentase hidup & $\mathrm{ns}$ & $\mathrm{ns}$ & $\mathrm{s}$ \\
2 & Tinggi tanaman & $\mathrm{ns}$ & $\mathrm{ns}$ & $\mathrm{ns}$ \\
3 & Diameter tanaman & $\mathrm{ns}$ & $\mathrm{ns}$ & $\mathrm{ns}$ \\
4 & Jumlah daun & $\mathrm{ns}$ & $\mathrm{ns}$ & $\mathrm{ns}$ \\
5 & Kekokohan tanaman & $\mathrm{ns}$ & $\mathrm{ns}$ & $\mathrm{ns}$ \\
\hline
\end{tabular}

Keterangan: $\mathrm{ns}=$ non signifikan, $\mathrm{s}=$ signifikan

Berdasarkan tabel pengamatan di atas dapat dilihat bahwa media tanam dan dosis pupuk PGPR tidak menunjukkan beda nyata yang signifikan terhadap parameter persentase hidup, tinggi tanaman, diameter tanaman, jumlah daun, dan kekokohan tanaman Gyrinops versteegii. Sementara kombinasi antara media tanam dan dosis pupuk menunjukkan adanya interaksi. Mengingat hasil analisis sidik ragam menunjukkan tidak adanya beda nyata pada perlakuan media tanam serta pada dosis pupuk PGPR, maka tidak perlu dilakukan uji lanjutan menggunakan uji beda nyata terkecil (BNT) terhadap perlakuan media tanam dan dosis pupuk. 
Hasil analisis sidik ragam menunjukkan bahwa tidak adanya beda nyata yang signifikan terhadap pertumbuhan tanaman gaharu. Hal ini diduga karena pengaruh $\mathrm{pH}$ pada pupuk PGPR menunjukkan nilai yang rendah yaitu sebesar 3,4 yang menurut BP3DP (2005) angka tersebut termasuk kedalam harkat yang sangat masam. Setyaningrum dan Saparinto (2014) menyatakan bahwa pH ideal untuk tanaman gaharu yaitu netral (5-7) karena pada $\mathrm{pH}$ netral fosfat berada dalam bentuk mono atau dikalsium fosfat yang paling tersedia bagi tanaman atau dapat diserap oleh tanaman. Hal lain yang menyebabkan pertumbuhan tanaman kurang baik diduga karena pengaruh cuaca pada saat penelitian sering terjadinya hujan, sehingga media tanam mengandung kadar air yang cukup tinggi, menyebabkan tanaman mengalami titik layu permanen.

Dugaan lain yang menyebabkan pertumbuhan tinggi tanaman kurang baik karena unsur hara nitrogen $(\mathrm{N})$ dari pupuk PGPR termasuk kedalam harkat yang rendah yaitu sebesar 0,11\%. Hardjowigeno (2007) menyatakan bahwa, nitrogen memiliki fungsi untuk memperbaiki pertumbuhan vegetative tanaman, seperti pertumbuhan tinggi tanaman, diameter batang, pertumbuhan daun dan akar tanaman. Tanaman yang tumbuh pada tanah atau media tanam yang cukup $\mathrm{N}$ akan berwarna lebih hijau.

\section{Kesimpulan}

yaitu:

Berdasarkan hasil analisis data penelitian dapat ditarik beberapa kesimpulan,

1. Jenis media tanam yang digunakan pada penelitian ini tidak memberikan pengaruh nyata terhadap persentasi hidup, tinggi tanaman, diameter, kekokohan, dan jumlah daun tanaman gaharu (Gyrinops verstegii).

2. Ragam dosis pupuk Plant Growth Promoting Rhizobakteri (PGPR) tidak memberikan pengaruh yang nyata terhadap pertumbuhan tanaman gaharu (Gyrinops verstegii).

3. Kombinasi antara media tanam dan pupuk PGPR menunjukkan adanya interaksi terhadap persentasi hidup tanaman gaharu (Gyrinops versteegii), namun pada parameter tinggi, diameter, jumlah daun, dan kekokohan tanaman tidak menunjukkan adanya interaksi terhadap pertumbuhan tanaman gaharu (Gyrinops versteegii).

\section{Daftar Pustaka}

Departemen Pertanian. 2005. Balai Penelitian Tanah. Badan Penelitian dan Pengembangan Pertanian.

Hairiah, K., D. Suprayogo, Widianto, Berlian, E.Sahara, A. Mardiastuning, R. H. Widodo, C. Prayogo, S.Rahayu, 2004. Alih guna lahan menjadi lahan agroforestri berbasis kopi: ketebalan seresah, populasi cacing tanah dan makroporositas.Agrivita 26:6880

Hardjowigeno. S. 2007. Ilmu Tanah. Akademika Pressindo. Jakarta.

Setyaningrum, H. D., dan Saparinto. C., 2014. Panduan Lengkap Gaharu. Penebar Swadaya. Jakarta.

Soeryoko, H. 2011. Kiat Pinter Memproduksi Kompos dengan Pengurai Buatan Sendiri. Lily Publisher. Yogyakarta.

Sumarna, Y. 2012. Budidaya Jenis Pohon Penghasil Gaharu. Pusat Litbang Produktivitas Hutan. Bogor.

Sutedjo, M. M. dan Kertasapoetra A.G., 1991. Pengantar IImu Tanah Terbentuknya Tanah dan Tanah Pertanian. PT Rineka Cipta. Jakarta. 